\title{
Zelda and Scott Fitzgerald and psychoanalysis: The construction of Tender Is the Night (1934)
}

\author{
Nuria Esteve ${ }^{1}$ and Rafael Huertas ${ }^{2}$ \\ ${ }^{1}$ Independent post-doctoral researcher. Psychiatry. Private practice. Atención al desarrollo integral (ADI). \\ Montesa 35, escalera izquierda, $1^{\circ} \mathrm{B}, 28006$ Madrid. \\ e-mail: nuriaestevediaz@hotmail.com \\ ORCID iD: http://orcid.org/0000-0002-9109-4393 \\ ${ }^{2}$ Instituto de Historia, CSIC. Albasanz, 26-28, 28037 Madrid. \\ e-mail: rafael.huertas@cchs.csic.es \\ ORCID iD: http://orcid.org/0000-0002-4543-7180
}

Submitted: 11 February 2017. Accepted: 2 August 2017

\begin{abstract}
This article analyzes the biographical and contextual elements which enabled Fitzgerald to incorporate the psychiatry of the time into Tender Is the Night (1934). The content of the novel is linked to Zelda Fitzgerald's mental illness and her admission to a Swiss psychiatric clinic in 1930. It also identifies the parallels between the doctors who treated the couple and those that appear in the novel, examining the elements used to construct fictional characters inspired by major figures in psychiatry during this period, including Oscar Forel, Eugen Bleuler and Carl Gustav Jung. Lastly, it evaluates the weight and significance of the discourse and the psychiatric and psychoanalytic concepts utilized by Fitzgerald in the novel.
\end{abstract}

KEYWORDS: Medicine and literature; Carl Gustav Jung; Schizophrenia; Literary modernism; 20th century's Narrative.

Citation / Cómo citar este artículo: Esteve, Nuria and Huertas, Rafael (2018) "Zelda and Scott Fitzgerald and psychoanalysis: The construction of Tender Is the Night (1934)". Culture \& History Digital Journal, 7 (1): e011. https://doi. org/10.3989/chdj.2018.011

RESUMEN: Zelda y Scott Fitzgerald y el psicoanálisis: la construcción de «Suave es la noche» (1934).- Este artículo analiza los elementos biográficos y contextuales que permitieron a Scott Fitzgerald realizar en Tender is the Night (1934) una aproximación a la psiquiatría de la época. Se relacionan los contenidos de la novela con la enfermedad mental de Zelda Fitzgerald y su ingreso en una clínica psiquiátrica suiza en 1930. Asimismo, se identifican los paralelismos existentes entre los médicos que trataron al matrimonio y los que aparecen en la novela, examinando los elementos que sirvieron para construir unos personajes de ficción inspirados en relevantes figuras de la psiquiatría del momento, como Oscar Forel, Eugen Bleuler o Carl Gustav Jung. Finalmente, se estima el peso y trascendencia del discurso y los conceptos psiquiátricos y psicoanalíticos manejados por Scott Fitzgerald en la novela.

PALABRAS CLAVE: Medicina y literatura; Carl Gustav Jung; Esquizofrenia; Modernismo literario; Narrativa siglo XX.

Copyright: (C) 2018 CSIC. This is an open-access article distributed under the terms of the Creative Commons Attribution 4.0 International (CC BY 4.0) License. 


\section{INTRODUCTION}

Francis Scott Key Fitzgerald (1896-1940) is among America's most important authors. Along with his wife Zelda (1900-1948), he was associated with the changes, hopes and luxury of the early 20th century, and with the fall of Victorian values that had been championed by preceding generations. However, they also experienced extreme financial difficulties and disillusionment later in their lives.

It is widely known that Fitzgerald's novels reflect many of his own life experiences (Sklar, 1967: 227). Throughout the 1930s, he had a great deal of contact with doctors and nurses due to his problems with alcohol, his insomnia, the tuberculosis he suffered from, and of course, Zelda's mental disorder. During this period, he wrote several stories which dealt with the subject of medicine from different points of view (Kerr, 2012). Tender Is the Night (1934) was part of that literary production. However, because of its content and the characteristics of the protagonists, it is an excellent novel for understanding this crucial time in his and Zelda's life, the period associated with her psychiatric admission in Europe.

On the following pages, we set out to analyze the biographical and contextual elements which enabled Fitzgerald to incorporate the psychiatry of the age into Tender Is the Night. To this end, we begin by assessing the importance of Zelda's mental illness, and his own illness, in constructing the story. Secondly, we identify the parallels between the doctors who treated the couple and those that appear in the novel, examining the elements used to create a group of fictional characters inspired by major figures in psychiatry during that period. Thirdly, we evaluate the weight and significance of the psychiatric and psychoanalytic discourse and concepts utilized by Fitzgerald in the novel.

Tender Is the Night was originally published in four issues of Scribner's Magazine between January and April of 1934, and then immediately released as a complete book, of which there were several editions. In 1951, Malcolm Cowley edited a revised version which became very famous. It followed a chronological order, eliminating the flashbacks found in the 1934 text. In recent years, publishers have returned to the text as it originally appeared. ${ }^{1}$

Work on the novel began in late 1925, the year in which The Great Gatsby was published. However, the book was the fruit of Fitzgerald's labor between 1932 and 1934, when he was living at La Paix, in the outskirts of Baltimore. The title is taken from a poem by John Keats called "Ode to a Nightingale":

Already with thee! Tender is the night / And haply the Queen-Moon is on her throne / Cluster'd around by all her starry Fays; / But here there is no light, / Save what from heaven is with the breezes blown / Through verdurous glooms and winding mossy ways. (Grube, 1965).

The novel is divided into three books. As it was first published, with no chronological order, Book One depicts the married couple made up of the protagonists, Dick and Nicole Diver, through the eyes of a young movie actress, Rosemary Hoyt. At the end of this first section, the first cracks begin to appear in Dick and his relationship with Nicole as a result of his affair with Rosemary. Book Two tells the story of Mrs. Diver as a mental patient. It focuses on her stay at a psychiatric hospital in Switzerland and the start of the love which connects her to her husband. It is in this part of the novel that we see the shift from Dick's power and control to his weakness and dependency at the end. The breakdown of Dick and Nicole's marriage is recounted in Book Three, along with their divorce and the emergence of a new, stronger and more independent Nicole. She ends up marrying Tommy Barban, who had always loved her. Dick returns to the United States to work as a small-town general practitioner, losing contract with his children and his ex-wife for good.

It is worth noting that the novel has a very cinematic structure, undoubtedly the result of Fitzgerald's association with Hollywood as a screenwriter. His experiences in the film world, while frustrating (Milford, 1975: 144), contributed to the novel's mise-en-scène, which is reminiscent of a movie. The narrator/camera presents the reader with information from the point of view of the different characters, sometimes Dick, sometimes Rosemary or Nicole. The flashbacks, so harshly criticized when the novel first appeared, also add to the sensation of being in a film. In short, the structure of the novel and the subject matter it dealt with reflected the original and groundbreaking vein the author sought to achieve. In addition to the narrative style of Tender Is the Night, the book makes numerous references to the film industry. Young Rosemary's profession allowed Fitzgerald to include a number of scenes and situations associated with the world of cinema.

\section{AUTOBIOGRAPHICAL CONTENT IN THE NOVEL}

Tender Is the Night is a novel with very obvious autobiographical content. It is not an autobiographical tale, in the sense meant by Philippe Lejeune (1975): it establishes no pact with the reader by means of which the same is informed of and accepts the veracity of the narrative as part of the author's life. Therefore, the above-mentioned autobiographical elements can only be confirmed by extratextual means.

It is generally known that Fitzgerald took inspiration from his own life when writing a good part of his stories and novels. In This Side of Paradise (1920), his protagonist Amory Blaine was a receptacle for the ideas and dreams of the writer when he was studying at Princeton (Bruccoli, 2002: 98-99). Tender Is the Night is a more mature novel whose main characters, Dick and Nicole, represent Scott and Zelda Fitzgerald, respectively, with all the emotional baggage they had accumulated over the years. Zelda's work also largely portrayed her biography, particularly Save Me the Waltz (1932).

Save Me the Waltz and Tender Is the Night were produced during a decisive period for the couple. The first 
was published in 1932 and the second in 1934. As we will discuss later, Mrs. Fitzgerald was admitted to a sanatorium in Switzerland in 1930. By that time, both of them had already engaged in extramarital relationships. Scott's father died in 1931, and his wife's passed away the following year. This circumstance was reflected in the plots of the two books.

Tender Is the Night begins with the American couple made up of Dick and Nicole Diver enjoying a stay on the French Riviera with a group of friends. In the spring of 1924, the Fitzgeralds moved to Paris, where they met Sara and Gerald Murphy, American expatriates. It was they who told the couple about the fine qualities of the French Riviera and it was to them that the author dedicated his novel: "To Gerald and Sara many Fêtes".

The Fitzgeralds took up residence at Villa Marie, located in Saint-Raphaël, towards the end of that spring. In the novel, Abe North, a friend of the Divers, explains to Rosemary shortly after meeting her that Dick and Nicole had built a house on the French coast, Villa Diana, which would enable them to avoid having to stay at Gausse's hotel (Fitzgerald, 2010: 20).

During that period, Scott was working on The Great Gatsby and Zelda spent much of her time alone and bored. On the Riviera, they met a group of French aviators who were staying nearby, in Fréjus. Among them was Edouard Jozan, with whom Zelda apparently had a romance in 1925 (Milford, 1975: 119-122). In Tender Is the Night, the character of Tommy Barban represents this young man. But Mrs. Fitzgerald was not the only one to have a romantic relationship outside their marriage, as Scott also met several women with whom he had romances. One of the most important was the actress Lois Moran. She was completely dazzled by the Fitzgeralds as a couple and the parallels between Lois Moran and the figure of Rosemary Hoyt are quite obvious.

It was during this period that Scott did a screen test as a result of Lois's efforts, in the hope that the two of them would make a film together (Donaldson, 1983: 54). Apparently, the fascination was mutual, which mostly likely irked Zelda. Curiously, in the novel, Dick Diver turns down the chance to do a screen test to make a movie with Rosemary (Fitzgerald, 2010: 74-75), yet this does not prevent a love from emerging between them, despite Nicole.

In 1932, Scott wrote the following to Zelda's psychiatrist: "Her affair with Edouard [Jozan] in 1925 and mine with Lois Moran in 1927, which was a sort of revenge, shook something out of us" (quoted in Donaldson, 1983: 70). Zelda also recounted both affairs in her novel Save Me the Waltz.

However, in his books, the author presented the subject of adultery as something degrading. He must have had difficulty with his relationship at the end of his life with Sheilah Graham, who he met in 1937, during his final stay in Hollywood, where he died in 1940. They never lived together and he never separated from Zelda (Donaldson, 1983: 198).

Other biographical elements worth noting are related to the relationship and family situation of both couples- real and fictitious. Both Fitzgerald and Diver married rich, popular and sought-after women who were diagnosed with schizophrenia. Emotional jealousy was a significant presence in the relationship of both couples. In the end, it is extremely revealing that both Zelda and Nicole's families felt that their respective husbands were responsible for their mental disorders. It is possible that the bad relationship between Scott Fitzgerald and his sister-in-law Rosalind Sayre (Donaldson, 1983: 89-90) gave him cause to exaggerate the character of Nicole's sister in Tender Is the Night.

Thus, we can see that the novel has significant biographical content, not only relating to the author's life, but also that of his wife. Life experiences shared by the two writers generated major conflicts because both intended to use the same experiences, with different interpretations, in producing their works.

As indicated earlier, one of the most important aspects of the Fitzgerald marriage, in creative terms, was Zelda and Scott's use of material from their own lives. Many shared experiences were repeated in the work of both writers. Scott became angry when he saw that Zelda had used episodes which he also wanted to include in his stories or novels. In addition, he published texts by her as if they were solely his or they put both of their names to works that had been created by Zelda alone, probably with the excuse that he was paid better as a writer. The disagreements resulting from the use of their private life for fictional purposes made an appearance early in their romantic relationship (Milford, 1975: 113-114).

Zelda had begun to devote all of her energies to dance in 1927, when she was 27. On her return to the United States in 1931, after her first psychiatric admission, she gave up ballet but continued her literary work. The death of her father resulted in a relapse and on February 12, 1932 she was admitted to the Phipps Clinic in Baltimore. Three months earlier, she had begun writing an autobiographical novel in Montgomery. She finished it a few weeks after returning from her stay at the clinic (Milford, 1975: 237 ff.). As indicated earlier, this novel was titled Save Me the Waltz. Zelda sent her manuscript to Maxwell Perkins, Scott's editor, without allowing her husband to see it first. When Scott found out, he was furious. The only thing he knew about his wife's book was that it covered the same terrain as he was dealing with in his novel, which would later become Tender Is the Night. He had the feeling that if Zelda's book were published first, his would seem to lack originality, tarnishing his reputation as a writer, which by that time had already been quite damaged. His wife's illness and all the expenses he needed to cover limited the amount of time he could spend on his novel, as he was writing stories that required less effort and brought in more money. He recalled having read Zelda a good part of what he had already finished for Tender Is the Night and at that time he was not sure to what extent she had used his ideas, whether consciously or unconsciously (Donaldson, 1983: 79 ff.).

Zelda, on the other hand, had a strong desire to become a productive person and not be an invalid for the 
rest of her life. She wanted to have a profession and be financially independent. She knew that Scott was not going to like her using the material he was also including, but at the end of the day, how could either one of them claim exclusive rights to it?

In the end, Save Me the Waltz was published after being reviewed by Scott. It tells the story of Alabama Beggs, a Southern beauty raised in a well-to-do family. Scott had some complaints about the role he played in his wife's novel, a rather unassuming character, while he had made her the heroine of his story. The reality was that neither Zelda's book nor Tender Is the Night was very well received by the public and critics (Ciges, 2012: 5-12).

One year after finishing Save Me the Waltz, Zelda planned to write a novel about madness. Apparently, Scott met with his wife's psychiatrists with the aim of focusing her energy on other areas rather than writing. Fitzgerald raised concerns to his wife, saying that she should not use the same material in her writing: "If you write a play, it cannot be a play about psychiatry and it cannot be a play laid on the Riviera, and it cannot be a play laid in Switzerland, and whatever the idea is it will have to be submitted to me." She responded: "I think we'd better get a divorce and any decision you choose to make with regard to me is all right because I cannot live on those terms, and I cannot accept them" (quoted in Donaldson, 1983: 84 ff.). Zelda never published another novel and they never divorced. After Scott's death, she returned to literature. She wrote a manuscript titled Caesar's Things, which contained much of the autobiographical material used in her first novel, mixed with religious visions and fantasies (Donaldson, 1983: 88).

Regarding the peculiar relationship between Scott and Zelda, let us recall the words of Edmund Wilson, a friend of the Fitzgeralds, who stated that "if ever there was a pair whose fantasies matched ... it was Zelda Sayre and Scott Fitzgerald" (Letter from Edmund Wilson to Nancy Milford dated July 19, 1965. Milford, 1975: 26). In spite of everything, the inscription on the gravestone under which both of their remains rest contains the final line of The Great Gatsby: "So we beat on, boats against the current, borne back ceaselessly into the past" (Fitzgerald, 2001: 115). It was to the past that both writers returned time and again to produce their literary legacy.

\section{REAL AND FICTIONAL DOCTORS: A LITERARY STRATEGY}

One of the most interesting aspects of Tender Is the Night are the many parallels the author establishes between the fictional psychiatrists that appear in the novel and certain figures in Swiss mental medicine. For example, it is possible to assert that Dick Diver is inspired by the figure of Jung, and that Dohmler is reminiscent of Bleuler. However, these similarities seem to reflect a very elaborate narrative strategy that enabled him to construct his characters following a very precise method. The few papers that have explored mental illness in Fitzgerald's novel have naturally drawn attention to the schizophrenia of Nicole and Zelda, and to the latter's stay at the Swiss clinics, but have not analyzed the aforementioned parallels (Frost, 2016), a possibility which is only briefly noted by Chris Messenger (2014: 110) in what is probably the most comprehensive work on Tender Is the Night to date.

\section{Dick Diver and Carl Gustav Jung}

The similarities between the novel's protagonist and Jung are very obvious, and without a doubt the most carefully thought out by Fitzgerald. In Tender Is the Night, he refers directly to "the great Jung, bland, super-vigorous, on his rounds between the forests of anthropology and the neuroses of school-boys" (Fitzgerald, 2010: 207), presenting him as the great leader of an entire generation of psychiatrists, to which Diver belongs. However, although Dick Diver contains much of Scott Fitzgerald himself, as we have already indicated, there can be no doubt that this character may also be considered an alter ego of Jung in the novel, making him especially complex. The biographical parallels between the two are quite striking: We are told that Doctor Diver is the son of a priest, as is Jung. The protagonist's father is described as a man without a very energetic temperament, like Jung's father (Werh, 1987). However, regarding this, it is most likely that Fitzgerald was depicting an opinion of his own father (Milford, 1975: 27). Jung was 55 years old when Zelda was admitted to Burghölzli, making it plausible that Scott could have learned that he was the son of a parish priest. Yet it is less likely that he would have known about the father's personality. Additionally, the novel tells us that Diver's great-grandfather was governor of North Carolina (Fitzgerald, [1934] 2010: 169), while Jung's paternal grandfather was a famous professor and doctor in Basel. In other words, both had forebears who played a respectable role in their respective communities.

Furthermore, it is known that Jung was forced to rely on scholarships and later loans in order to complete his medical studies (Wehr, 1987). Doctor Diver also received a scholarship to study at Oxford (Fitzgerald, 2010: 123). Thus, neither Diver nor Jung came from exceedingly wealthy backgrounds. It was their efforts, along with their intelligence, which enabled them to achieve their goals. Nevertheless, both married very rich women.

Lastly, it is worth noting that Jung reached the rank of lieutenant and was part of a medical detachment during World War I, while Nicole addresses Dick as "Captain Diver" in the letters she sends to him while he is at the front during the same conflict. Fitzgerald was called to the ranks as a lieutenant in the infantry and aide-de-camp to General John A. Ryan, although he never fought at the front (Espejo, 2011).

Scott Fitzgerald not only took an interest in the figure of Jung, but he also read some of his works, which must have influenced the psychological construction of Dick Diver. The American writer was extremely interested in the social conscience and the historical vision of culture, which would justify his greater interest in the work of Jung over that of Freud. Jung placed more emphasis on 
the collective unconscious and the social, rather than the biological, basis of human behavior. One of Scott Fitzgerald's biographers, Robert Sklar, states that:

What Fitzgerald learned from his reading in the works of Jung and in his conversations with Jung's students is a matter open only to speculation. Possibly his own interest in social types -his search for "Our Type" that had eluded his reach for nearly five years- led him to Jung's general descriptions in Psychological Types. There Jung makes his famous distinction between extraverted and introverted types and describes their various forms and characteristics. To claim that the character of Dick Diver was drawn out of Jung's typology obviously distorts Fitzgerald's mode of artistic creation. And yet it is difficult not to believe that he gained from Jung organizing and shaping insights into the psychology of his genteel romantic hero. (Sklar, 1967: 263)

Scott Fitzgerald gave form to a masculine character filled with positive attributes and made him a professional with a great future. To do so, who better to refer to than a famous and attractive psychiatrist such as Carl Gustav Jung? However, as accustomed as Fitzgerald was to depicting his own aspirations and failures in his work, he did not neglect to also endow Dick with many of his personal qualities and defects, such as his inveterate alcohol consumption. Doctor Diver ended up a failure, despite Nicole's being cured, just as Fitzgerald himself must have felt in relation to Zelda's illness and his own life.

\section{Franz Gregorovius and Oscar Forel}

The character of Franz Gregorovius, friend and colleague of Dick Diver, represents a psychiatrist who worked at Dohmler's clinic on the banks of the Zurichsee. Gregorovius had been born in the Canton of Vaud and was a few years older than Dick. He is described as follows:

He was the third of the Gregoroviouses -his grandfather had instructed Kraepelin when psychiatry was just emerging from the darkness of all time. In personality he was proud, fiery, and sheep-like- he fancied himself as a hypnotist. If the original genius of the family had grown a little tired, Franz would without doubt become a fine clinician. (Fitzgerald, 2010: 127)

The similarities to Oscar Forel are quite close. He was born in Zurich and served as director of Les Rives de Prangins clinic, located on Lake Geneva in the Canton of Vaud, where Zelda had stayed. His father was the famous psychiatrist Auguste-Henri Forel (1848-1931) (Forel, 1937), who had been the director of the Burghölzli Clinic between 1879 and 1898 (Parent, 2003), and had shown a great interest in hypnosis, clearly influenced by Hippolyte Bernheim and the Nancy School (Klein, 2010). Later, his son Oscar also used this technique in his treatments and even hypnotized Zelda (Milford, 1975: 196).

What is more, Franz Gregorovius was Vaudois by birth and worked on the Zurichsee, just the opposite of
Oscar Forel, who was born in Zurich and had his clinic in the Canton of Vaud. Scott Fitzgerald associated Franz Gregorovius's grandfather with Kraepelin. It is possible that the novelist would name Kraepelin as an important figure of the time, although it should be noted that there was in fact a professional relationship between the German psychiatrist and Auguste-Henri Forel, Oscar's father, as demonstrated by the existence of correspondence between the two (Ackerknecht, 1963).

On May 22, 1930, Mrs. Fitzgerald transferred to the Valmont Clinic in Switzerland. In fact, it was Oscar Forel who was the first to conduct a psychiatric evaluation and give a diagnosis of schizophrenia, transferring her to Les Rives de Prangins, the clinic on Lake Geneva where he was the director (Letter from Doctor Oscar Forel to Nancy Milford dated March 9, 1966. Milford, 1975: 177 ff.). Lucia, the daughter of James Joyce, was also treated at this same psychiatric facility, with the same diagnosis (Ellmann, 1959: 677, 687-688). According to Nancy Milford, Prangins was a beautiful place, with well-maintained gardens, tennis courts and seven villas where the patients were housed. Only a limited number of patients were admitted and the doctors and their families also lived on-site, enabling them to take part in the life of the community (Milford, 1975: 178). Scott Fitzgerald probably took his inspiration from this place when writing about the sanatorium established by Dick and Franz Gregorovius in Tender Is the Night. The doctors in the novel also lived on the hospital grounds with their respective families. The novel describes a clinic which is among the best-appointed in Europe, built in a modern style and resembling "a small, scattered, yet deceitfully integrated village... so that the plant was a thing of beauty, visited by every psychologist passing through Zurich". There were two houses known as the Eglantine and the Beeches, where the most serious patients lived, a garden cared for by the patients and three workshops: one for carpentry, a book-bindery and a third used for beadwork, weaving and brass objects (Fitzgerald, 2010: 193-194). At Prangins, the Eglantine was the name of one of the buildings where the most serious patients were housed and where Zelda spent some time (Milford, 1975: 183).

One final detail which links the Forels to Scott Fitzgerald and Tender Is the Night is related to alcoholism. It is widely known that Scott had serious problems with alcohol. His daughter recognized that the two great anxieties with which her father had wrestled throughout his life were money and drink (Donaldson, 1983: 114). Until well into the novel, the problems related to this toxin are reflected in the character of Abe North, who had once been a precocious and brilliant musician but had not composed anything for years. To a certain extent, this figure somewhat recalls Scott Fitzgerald himself, that young man who had published a book This Side of Paradise which brought him fame, money and the girl of his dreams, but then went through years of creative drought without publishing another novel, drowning his failure in parties and alcohol. 
In the final chapters of Book Two and throughout Book Three, Dick Diver's alcoholism becomes increasingly obvious. He sought refuge from the enormous sadness he felt in alcohol. When he was intoxicated, his behavior turned haughty and problematic, tightening the vicious circle in which he found himself with the resulting enmities and conflicts. Dick symbolizes failed love, the break-up with the woman he had loved so much in his youth and who he ended up hurting, in addition to isolation and social rejection. The American writer ultimately suffered all of these disappointments himself, equally brought on by his relationship with alcohol.

At Burghölzli, with whose school of thought the Fitzgeralds had so much contact, both Auguste-Henri Forel and Eugen Bleuler, in their capacity as directors of the clinic, barred employees of the institution from consuming alcohol (Makari, 2012: $241 \mathrm{ff}$.). While Zelda was at Prangins, Scott wrote two stories in which the characters received the anti-alcoholic treatment practiced at the Burghölzli Clinic: "One Trip Abroad" (Fitzgerald, 2003: 577-597) and "Babylon Revisited" (Fitzgerald, 2003: 616-633). Doctor Forel himself was concerned about how much Scott was drinking. In one of the letters Zelda sent to her husband while at Prangins, she told him: "Doctor Forel has asked me to ask you whether you have given up drinking, so I'm asking you" (Letter from Zelda to Scott in Fitzgerald, Scott and Zelda, 2003).

\section{Doctor Dohmler and Eugen Bleuler}

Another key figure in the world of psychiatry reflected in the novel is no less than Eugen Bleuler, who takes the form of Doctor Dohmler. Bleuler followed Auguste Forel as both director of Burghölzli asylum and head of the psychiatry department at the University of Zurich, where he taught from 1886 to 1927 (Joos-Bleuler, 2011). The two aspects of his work worth noting here are the formulation of the concept of schizophrenia and his relationship with Freud. Bleuler published Dementia praecox oder Gruppe der Schizophrenien (1911), in which he revised and conceptually modified Kraepelin's “dementia praecox" characterizing the symptoms not based on their evolution, but rather on what he considered their core psychopathological trait: the splitting of the ego. This new perspective led Bleuler to introduce the neologism "schizophrenia" (literally, "splitting of the mind") (Garrabé, 2003; Novella and Huertas, 2010). His proposal was not limited to suggesting a mere change in terminology, but instead stemmed from a new view of the mental patient and his madness in which the clinical picture -symptoms and evolution- was relegated to second place and psychopathological interpretation took on central importance (Gruhle, 1913).

In this regard, Bleuler's debt to Sigmund Freud, and to psychoanalysis, has been subject to different evaluations. For some authors, the point of departure and originality of Bleuler's conceptions are due to his psychoanalytic approach to the symptoms of schizophrenia (Bercherie, 1980: 154), while for others, this influence is more difficult to establish, as the impact of psychoanalysis reached Bleuler via Jung and was heavily influenced by the associationist psychology of WilhelmWundt and Theodor Ziehen (Colodrón, 1983). In any case, the fact is that for some time at least, there was what might be called a Zurich-Vienna axis and an intense relationship between Bleuler and Freud (Dalzell, 2007), although this would later become ambivalent and ultimately cease to exist (Falzeder, 2007).

During the first third of the 20th century, the Burghölzli Clinic and the Zurich School had become undisputed leaders in mental medicine and Bleuler was a major figure in Swiss and European psychiatry. According to Nancy Milford (1975: 198), Bleuler evaluated Zelda Fitzgerald at Oscar Forel's request, confirming the diagnosis of schizophrenia. In Tender Is the Night, Doctor Dohmler represents the authority and clinical experience typical of the head of a school. Dohmler (Bleuler) supervises Gregorovius (Oscar Forel) and also makes a note of the diagnosis of schizophrenia in the chart for Nicole (Zelda):

Diagnostic: schizophrénie. Phase aiguë en décroissance. La peur des hommes est un symptome de la maladie, et n'est point constitutionnelle. Le pronostic doit rester reservé. (Fitzgerald, 2010: 137). ${ }^{2}$

Dohmler's ascendency over his subordinates also makes an appearance when, following the return of Dick Diver from the front during the Great War, he interfered in the latter's relationship with Nicole. When Diver returned to Switzerland, Franz Gregorovius, his colleague and friend, summarized what had happened to the girl. Dick had met her briefly before going off to war and as a result of this encounter, she had written him many letters, which had given her doctors clues as to her mental state. Dick began seeing Nicole regularly and they fell in love. Although Doctor Dohmler had initially believed that it would be therapeutic for the girl to write the letters, he began to grow concerned about the situation and ended up warning the young doctor that he should put an end to "this so-called "transference"" and that "it is a professional situation" (Fitzgerald, 2010: 149-150). Doctor Diver obeyed his mentor and distanced himself from his patient. It was only later, following a chance encounter with Nicole, that they resumed the relationship, despite the opposition from his colleagues.

\section{ROMANTIC RELATIONSHIPS IN A THERAPEUTIC SETTING}

The narrative strategy which enabled Scott Fitzgerald to construct the characters of Dick Diver and the other doctors in Tender Is the Night is also evident in the formation of the female protagonist. As noted earlier, Nicole is directly based on Zelda Fitzgerald. However, her description includes aspects shared with Emma Jung and Sabina Spielrein.

Emma Jung was seven years younger than her husband Carl, the same age gap as between Nicole and Dick. Fol- 
lowing her wedding, Emma took up residence at the Burghölzli Clinic with her husband (Werh, 1987). Similarly, Nicole was responsible for decorating and organizing the clinic which Dick opened with Doctor Gregorovius (Fitzgerald, 2010: 193-195). Both were rich heiresses, which provided significant financial relief and greater independence for their husbands in their professional undertakings. Zelda was the daughter of an Alabama judge and belonged to a higher social class than Scott, but her family were not multimillionaires. However, the most striking parallel with Doctor Diver, who falls in love with his patient Nicole, can be found in the romantic relationship between Doctor Jung and his patient Sabina Spielrein.

In the summer of 1904, Sabina Spielrein was admitted to the Burghölzli Hospital, whose director, as we know, was Eugen Bleuler. Carl Gustav Jung was the doctor charged with treating the young patient. The psychoanalytic therapy practiced by Jung, based on suggestion and association-centered practices, lasted three months. Sabina gradually recovered, ended up studying medicine and also become a psychoanalyst (Covington and Wharton, 2003).

In 1977, the Jungian psychoanalyst Aldo Carotenuto obtained a set of documents found in the basement of a building which years earlier had been the headquarters of the Institute of Psychology in Geneva. The papers had belonged to Doctor Sabina Spielrein, who had worked at the institute in the early 1920s. They were letters she had exchanged with Freud and Jung, as well as her personal diary for the years 1909 to 1912 . Using this material, Aldo Carotenuto wrote a book titled Diario di una segreta simmetria. Sabina Spielrein tra Freud e Jung (1980), in which the romantic relationship between Jung and Spielrein is clear, as is the role Freud played in it.

After beginning their relationship, Jung began to fear that she would make it public and that this would affect his professional career. Sabina and Jung each decided, separately, to ask Freud to mediate in this matter. Freud had already heard about the relationship between them, but Jung was his "favored son" and he decided to characterize what was happening as an unfortunate consequence of the type of treatment they were engaged in. The problem of transference and countertransference emerged as one of the central elements of the relationship between patient and therapist (Freud, 1959) and Freud encouraged the young Russian to distance herself from Jung (Appignanesi and Forrester, 2000).

It is quite unlikely that Scott Fitzgerald would have known about this relationship, but it is striking that his protagonist, who as we have seen was partially inspired by the figure of Jung, fell in love with his patient. In this regard, it is worth highlighting the romances which early therapists had with their female patients. In Freud's Woman, Lisa Appignanesi and John Forrester examine the women who surrounded the father of psychoanalysis at different moments in his life: Lou Andreas Salomé, Helene Deutsch and Marie Bonaparte. But it is also notable that there were various situations in which Freud got involved, in one way or another, in a number of romantic relationships which emerged in the therapeutic setting between early psychoanalysts: Bertha Pappenheim and Josef Breuer (Borch-Jacobsen, 1996); the aforementioned Sabina Spielrein and Jung (Simón, 2014); Loë Kann and Joan Riviere with Ernest Jones. Haynal (1992) also adds the relationship between Elma Pálos and Sándor Ferenczi (Roazen, 1997).

How much Scott Fitzgerald was aware of this type of relationship is difficult to ascertain. For example, we do know that the gossip which arose around Ferenzci's relationship with Elma Pâlos made it necessary for her to change her identity when the correspondence between the Hungarian analyst and Freud was published quite a few years later (Haynal, 1992). It is therefore within the realm of possibility that certain rumors about Jung's love affairs might have reached the writer's ears. Although this cannot be confirmed, it is certain that Scott Fitzgerald was familiar with the psychoanalytic concept of transference, as demonstrated in the novel when Gregorovius warns Dick Diver that the patient who had written him letters while he was at the front had developed "a transference of the most fortuitous kind" (Fitzgerald, 2010: 128).

After the war, as noted earlier, Dick would grow closer to the girl, against the advice of his colleagues, demonstrating countertransference. At the end of the novel, the transgression in the therapeutic context ends up taking its toll on Dick, which becomes clear when Nicole finds out that her husband is flirting with the daughter of a patient:

\footnotetext{
"Listen to me-this business about a girl is a delusion, do you understand that word?'

"It's always a delusion when I see what you don't want me to see." (Fitzgerald, 2010: 202-203).
}

For the first time, Nicole explains to her husband that she knows he did not take into account that she was a patient when considering whether she had truly fallen in love with him or if it was the result of her illness and the very special relationship which is established between doctor and patient.

\section{TENDER IS THE NIGHT AND PSYCHOANALYSIS}

In addition to employing the concept of transference, which we have just discussed, Tender Is the Night contains other references to psychoanalysis that, while on the superficial side, denote Scott Fitzgerald's interest in the field.

As mentioned earlier, Zelda was first admitted to a Swiss psychiatric clinic in 1930. Scott remained in the country for more than a year, living in different cities near the sanatorium. He wanted to understand the sickness from which his wife was suffering and tried to help with her cure. As a result, he began reading works related to psychiatry. During this time, he wrote to a friend: "Have you read The Story of San Michele or Fantasia of the Unconscious? You can't miss them" (Turnbull, 1963: 222).

The references to these two works are extremely illuminating. In The Story of San Michele (1929), the Swedish 
doctor and writer Axel Munthe recounts the adventures -partially autobiographical- of a doctor who criticizes Charcot and assigns great importance to the subjectivity of his patients. But perhaps the most important aspect is that Fitzgerald saw that a novel featuring a doctor as the main character could be a great success (Sklar, 1967: 259). In Psychoanalysis and the Unconscious (1921) and Fantasia of the Unconscious (1922), David Herbert Lawrence, a great reader of Freud, sets out his points of view on psychoanalysis. These two works, and two authors, fully represent literary modernism and they piqued the interest of another writer who drank from the well of the art nouveau era, although given his age and career, we might say he was closer to what would later come to be known as art deco. It is highly likely that, even if he did read some of Jung's work, Scott Fitzgerald was more imbued with literary modernism, which as we know, was exceedingly interested in human psychological and psychopathological aspects (Micale, 2004; Sass, 1992). The influence of D.H. Lawrence on our author has been comprehensively analyzed (Wexelblatt, 1987; Brad, 2000).

Fitzgerald's prose is highly poetic and evocative. It is filled with metaphors, symbols -generally sexual in natureand dreams. The use of flowers and horses to indicate sexual interest or encounters between characters is noteworthy.

Nor does the plot of the movie, Daddy's Girl, in which the young actress Rosemary had just starred when she met the Divers, seem accidental in a book which repeatedly plays with symbols. It was the story of a young woman who took on corruption with great bravery. She and her father ended up finding each other:

\section{A lovely shot of Rosemary and her parent united at the last in a father complex so apparent that Dick winced for all psychologists at the vicious sentimentality. (Fitzgerald, 2010: 74).}

In 1913, Gustav Jung first introduced the concept of the "Electra complex" to refer to the female version of the Oedipus complex in a text (Jung, 1913) which was translated into English two years later (Jung, 1915). He subsequently abandoned this term, taking up others such as the "father complex." This provides confirmation that Fitzgerald had read Jung and used some of his terms in the novel.

Lastly, the protagonist's dreams in Tender Is the Night merit a short discussion. Some of these dreams featured Nicole and were pleasant: "in dreams he saw her walking on the clinic path swinging her wide straw hat" (Fitzgerald, 2010: 155). They fulfilled his longing to see her waiting for him again. However, other dreams were more disturbing. After eighteen months at the clinic he had opened in Switzerland with Doctor Gregorovius, his relationship with Nicole is not good. He feels more and more trapped and has difficulty determining when to act as a doctor and when to be a husband. As did Freud and many other therapists and patients, Diver writes down his dreams on waking in order not to forget them and to be able to analyze them. The deterioration of his marriage, the feeling of dismay that overcomes him and the failure that he had feared filter into his dreams, as his mind is no longer censored by wakefulness. This may have given rise to a gloomy dream, which spoke of catastrophes. It is possible that the psychiatrist wanted to get rid of the bond which he felt tied him to his wife, in some regard desiring the disaster that putting an end to his marriage would entail. Although describing characters' dreams is a common stylistic resource in literature, there can be no doubt that the influence of psychoanalysis and The Interpretation of Dreams (Die Traumdeutung, 1900) is clear in Tender Is the Night. In short, it is possible to state that, although it may be in an ingenuous and superficial manner, psychoanalysis is a strong presence in the novel and is to a large extent one of the crucial characteristics for understanding it in its context.

\section{CONCLUSIONS}

Tender Is the Night reflects Scott Fitzgerald's interest in psychiatry and psychoanalysis as a result of his wife Zelda's stay at a Swiss psychiatric clinic, where she was diagnosed with schizophrenia. Fitzgerald constructs a narrative which is fictional but largely inspired by his own experiences and those of his wife during this period, the early 1930s. It was for this reason that Fitzgerald was in contact with Oscar Forel and Eugen Bleuler, taking an interest in the prestigious Zurich psychiatric school, particularly Carl Gustav Jung. The doctors that appear in the novel are based on these figures in Swiss mental medicine. As regards the psychiatric concepts dealt with, the most noteworthy is the schizophrenia suffered by Nicole/ Zelda. Using the concepts of transference, countertransference and the "father complex", as well as references to dreams and the use of sexual metaphors and symbols, although barely developed, point to Fitzgerald's reading around psychoanalysis and interest in these matters. Nonetheless, his most direct intellectual points of reference were writers imbued with the literary modernism and psychology of the Belle Époque. All of this makes Tender Is the Night an essential contribution by the field of literature to the "psy-culture" of the early decades of the 20th century.

\section{ACKNOWLEDGEMENTS}

This work was carried out under Research Project HAR2015-66374-R (MINECO/FEDER).

\section{NOTES}

1 The edition used in preparing this article is Fitzgerald, Francis Scott (2010) Tender Is the Night. Penguin Books, London. The structure reflects the original 1934 version.

2 In French in the original.

\section{REFERENCES}

Ackerknecht, Erwin H. (1963) "A letter of Emil Kraepelin to Auguste Forel". Schweizer Archiv für Neurologie, Neurochirurgie und Psychiatrie, 91: 11-13. 
Appignanesi, Lisa and Forrester, John (2000) Freud's Women. 2nd ed. Other Press, New York.

Bercherie, Paul (1980) Les fondements de la clinique Histoire et structure du savoir psychiatrique. Navarin, Paris.

Bleuler, Eugen (1911) Dementia praecox oder Gruppe der Schizophrenien. Franz Deuticke, Leipzig.

Borch-Jacobsen, Mikkel (1996) Remembering Anna O.: A Century of Mystification. Routledge, New York.

Brad, Dana (2000) "Tourism and Modernity in Tender Is the Night". In F. Scott Fitzgerald: New Perspectives, edited by Bryer, Jackson; Margolies, Alan and Prigozy, Ruth. University of Georgia Press, Athens: 130-141.

Bruccoli, Matthew Joseph (2002) Some Sort of Epic Grandeur: The Life of F. Scott Fitzgerald. 2nd rev. ed. University of South Carolina Press, Columbia.

Carotenuto, Aldo (1980) Diario di una segreta simmetria. Sabina Spielrein tra Jung e Freud. Astrolabio, Rome.

Ciges, Miguel (2012) "Preface". In Fitzgerald, Zelda, Resérvame el vals. Román y Bueno editores, Granada.

Colodrón, Antonio (1983) Las esquizofrenias. Siglo XXI, Madrid.

Covington, Coline and Wharton, Barbara (2003) Sabina Spielrein: Forgotten Pioneer of Psychoanalysis. Brunner-Routledge, New York.

Dalzell, Thomas G. (2007) “Eugen Bleuler 150: Bleuler's reception of Freud". History of Psychiatry, 18: 471-482.

Donaldson, Scott (1983) Fool for Love: A Biography of F. Scott Fitzgerald. Delta, New York.

Ellmann, Richard (1959) James Joyce. Oxford University Press, New York.

Espejo, Beatriz (2011) "F. Scott Fitzgerald: Cronista y personaje". Revista de la Universidad de México, 88: 44-50. http://www. revistadelauniversidad.unam.mx/8811/pdf/88espejo.pdf. [accessed 27/August/2014]

Falzeder, Ernst (2007) "The story of an ambivalent relationship: Sigmund Freud and Eugen Bleuler". Journal of Analytical Psychology, 52 (3): 343-368.

Fitzgerald, Francis Scott (1920) This Side of Paradise. Scribner, New York.

Fitzgerald, Francis Scott (2001) [1925] The Great Gatsby. Wordsworth Editions Limited, Hertfordshire.

Fitzgerald, Francis Scott (2003) The Short Stories of F. Scott Fitzgerald. Scribner, New York.

Fitzgerald, Francis Scott (2010) [1934] Tender Is the Night. Penguin Books, London.

Fitzgerald, Francis Scott and Fitzgerald, Zelda (2003) Dear Scott, Dearest Zelda: The Love Letters of F. Scott and Zelda Fitzgerald. Bloomsbury, New York.

Fitzgerald, Zelda (1932) Save Me the Waltz. Scribner, New York.

Forel, Auguste (1937) Out of My Life and Work. Translated by B. Miall. W.W. Norton, New York.

Freud, Sigmund (1959) [1910] "The future prospects of psychoanalytic therapy". In Collected Papers. Basis Books, New York: 285-296.

Frost, Jessica (2016) "F. Scott Fitzgerald and mental illness in Tender is the Night". Hektoen International. A Journal of Medical Humanities, 8. http://hekint.org/f-scott-fitzgerald-and-mentalillness-in-tender-is-the-night/. [accessed 3/May/2017]

Garrabé, Jean (2003) La schizophrénie. Un siècle pour comprendre. Empecheurs de penser en Rond, Paris.
Grube, John (1965) "Tender is the Night: Keats and Scott Fitzgerald". Dalhousie Review, 44 (4): 433-441.

Gruhle, H. W. (1913) "Bleulers schizophrenie und Kraepelins dementia precox". Zeitschrift für die gesamte neurologie psychiatrie, 17: 114-133.

Haynal, André (1992) "Introduction". In The Correspondence of Sigmund Freud and Sándor Ferenczi, Volume 1, 1908-1914. The Belknap Press of Harvard University Press, London.

Joos-Bleuler, Tina (2011) "Being a Member of the Bleuler Family". Schizophrenia Bulletin, 37 (6): 1115-1117. https://doi.org/ $10.1093 / \mathrm{schbul} / \mathrm{sbr} 135$

Jung, Carl Gustav (1913) Versuch einer Darstellung der psychoanalytischen Theorie. Franz Deuticke, Leipzig und Wien.

Jung, Carl Gustav (1915) The Theory of Psychoanalysis. Journal of Nervous and Mental Disease. Publishing Company. New York.

Kerr, Lisa (2012) "A lost decade: exploring F. Scott Fitzgerald's contribution to the illness canon through the doctor-nurse series and other healthcare stories of the 1930s". Medical Humanities, 38 (2): 83-87.

Klein, Alexandre (2010) "Nouveau regard sur l'Ecole hypnologique de Nancy à partir d'archives inédites". Le Pays Lorrain, 4: 337-348.

Lawrence, David Herbert (1921) Psychoanalysis and the Unconscious. Martin Secken, London.

Lawrence, David Herbert (1922) Fantasia of the Unconscious. T. Seltzen, New York.

Lejeune, Philippe (1975) Le Pacte autobiographique. Seuil, Paris.

Makari, George (2012) Revolución en mente. La creación del psicoanálisis. Quinta del Agua Ediciones, Barcelona.

Messenger, Chris (2014) Tender is the Night and F. Scott Fitzgerald's Sentimental Identities. The University of Alabama Press, Tuscaloosa.

Micale, Mark S. (editor) (2004) The Mind of Modernism: Medicine, Psychology, and the Cultural Arts in Europe and America, 1880-1940. Stanford University Press, Stanford.

Milford, Nancy (1975) Zelda Fitzgerald. Penguin Books, England.

Munthe, Axel (1929) The Story of San Michele. John Murray, London.

Novella, Enric J. and Huertas, Rafael (2010) «El síndrome de Kraepelin-Bleuler-Schneider y la conciencia moderna: una aproximación a la historia de la esquizofrenia». Clínica y Salud, 21 (3): 205-219.

Parent, André (2003) "Auguste Forel on Ants and Neurology". The Canadian Journal of Neurological Sciences, 30 (3): 284-291.

Roazen, Paul (1997) "Elma Lauryk: Ferenczi's Step-Daughter". European Journal of Psychoanalysis, 5. http://www.psychomedia.it/jep/number5/roazen.htm. [accessed 20/May/2015]

Sass, Louis A. (1992) Madness and Modernism: Insanity in the Light of Modern Art, Literature, and Thought. Basic Books, New York.

Simón, Trinidad (2014) Juego limpio: Sabina Spielrein entre Jung y Freud. Editorial Psimática, Madrid.

Sklar, Robert (1967) F. Scott Fitzgerald: The Last Laocoön. Oxford University Press, New York.

Turnbull, Andrew (editor) (1963) The Letters of F. Scott Fitzgerald. Charles Scribner's Sons, New York.

Wehr, Gerhard (1987) Jung: A Biography. Random House, New York.

Wexelblatt, Robert (1987) "F. Scott Fitzgerald and D.H. Lawrence: Bicycles and Incest". American Literature, 59 (3): 378-388. 